\title{
"The Right Step towards a Woman's Satisfaction?": Washing Machine as a New Piece of Technology and the Construction of the Role of Women as Housewives in Socialist Slovenia
}

\author{
POLONA SITAR \\ Young researcher and PhD student, \\ Institute of Culture and Memory Studies, Ljubljana
}

\begin{abstract}
This article discusses political implications of the fact that technological development and consumption in socialism are nowadays shown as a failed project of the socialist production. This generates a view that the Yugoslav socialism was never a part of modernity. The paper also argues that, unlike in the case of non-mechanical hand washing, the washing machine as a new piece of technology enabled the participation of men in doing laundry for the first time because of the stereotypical relationship between men and technology. The article also discusses ambiguities in understanding, using and relocating the time saved by using a washing machine (which promised the reduction of time) used for housework.
\end{abstract}

Key words: Washing machine, housework, gender, technological development, socialism

\section{INTRODUCTION}

"You are interested in the washing machine?" asked Mila with amazement in her voice. A kind of provisional, uncertain smile appeared on her face that announced she was trying to establish if I might be joking. "But the first washing machine that we got..." Mila continued and, as she let out a deep sigh, she waved by her hand: "You know what a joy this was! It was no longer necessary to wash by hand. Neighbours came to see it and asked: Does it really wash? Does it wash well?"

Mila was born in 1927 in Dol near Ljubljana and we met for coffee in one of Ljubljana's homes for the elderly. Deriving from her story and her experiences with the washing machine we will try to understand what it meant for women to purchase a washing machine and how this affected their lives. The 
article is based on Mila's narrative, because she was one of the informants that most frequently pointed to the changes introduced into her household by the use of the washing machine. She was also an employed worker, a mother and a housewife, therefore her story is representative of more women. Through understanding technological development in socialism we will try to understand to what extent the washing machine as a new piece of technology transformed the lives of people in the period of socialism in Slovenia (1945-1991) and Yugoslavia in general.

After the introduction of self-management in Yugoslavia, the official discourse on consumption produced mixed messages. On the one hand, consumption was seen as a social evil, and on the other as a reward for workers. The Slovenes found themselves in a paradoxical position, because they believed in self-management, Tito and the non-alignment movement, but also in washing machines, televisions and other consumer products (Repe 1998). With the rapid rise in the Yugoslav standard of living between 1960 and 1970, which was also influenced by a high level of employment and wage increases, the belief that the quality of life is a need and also a right of the Yugoslavs, became more and more widespread.

By understanding the connection between gender and technology we can arrive at more complete understanding of how gender is embodied and understood. Therefore, in this paper we will be interested in finding out how the washing machine effected the gender division of labour. Does technological development and mechanisation in the household necessarily bring more free time? How did women spend the time that they gained by using washing machines, how did they relocate it and how were they guided by the public discourse?

Researchers that use the oral history approach explore women's history from the perspective of subjective interpretation, arguing that the oral history method is usable not to obtain objective, but subjective information (see, among others, Oakley 2003; Thompson 2000; Riessman 1987; Ritchie 1995; Stanley 1992). As Thomson stated (2000: 296, 301), the individual's life is actually a means of historical experience, therefore oral history interviews provide a view of the transmission of values over generations, give a better insight into cultural patterns and emotional configurations.

Our analysis consists of open interviews with mainly female informants, born before WW2, who lived their active lives in the time of socialism. We will focus on a single woman, Mila, but we will also include discourses of other informants to provide a broader context. ${ }^{1}$

\footnotetext{
${ }^{1}$ Interviews were carried out between 2013 and 2015 in the framework of fieldwork for my doctoral dissertation. Informants were selected by ethnographic snowball method. After I grew closer to my central informant Mila and conducted approximately 5 interviews with her, I asked her to introduce me to her social network of people whom I later interviewed and conducted approximately 30 interviews.
} 
The advantage of using this interviewing technique is that the informant is thinking about her life in an "emic way" (Ramšak 2002: 94-5; Dijanić et al. 2004), which enables more spontaneity because the informant can say what s/he considers important and that also reflects her emotions, attitudes, knowledge and beliefs. My informants come from villages and towns and different social classes, therefore, instead of perceiving women as a collective entity, we will pay attention to the multiple differences within the category of "women" (Antić Gaber, quoted in Squires 2009: 344).

We argue that by researching the ambivalence and ambiguity of the lifeworlds of female informants we can create new ways of conceptualising and writing about gender, which we perceive not only as a created identity, but also as embodied performance. By studying seemingly fixed categories, such as maternity and femininity, it is necessary to draw attention to their cultural construction, in particular, how informants understand, negotiate, use and embody ideas and practices. This enables us to challenge the established assumptions about the universal subordination of women and avoid simplistic writing about their social subordination and patriarchy (see Abu-Lughod 1990; Ghodsee 2005; Gal and Kligman 2000; Patico and Caldwell 2002 etc.).

In addition, we will include a textual analysis of advertisements for washing machines and washing powders from the magazine Naša žena (Our Woman), which has been published continuously since 1941 making it the oldest Slovenian women's and family magazine. Also, excerpts from the newspaper Tovariš (Comrade), which was published between 1945 and 1973 will be included to provide a better understanding of the public and official language of the socialist system regarding housewives and domestic work. For a better understanding of the official discourse of the socialist system regarding domestic work through the perspective of the establishment of public laundries and washing machines in the early period of socialism we will analyse the Sodobno gospodinjstvo (Modern household) ${ }^{2}$ newspaper and the Naša žena magazine.

The advertisements will be analyzed using Barthes' (2000 [1957]) theoretical model of representation, which we will explain only briefly due to a lack of space. According to Barthes, the picture communicates information about the object it depicts (the denotative level) and also the wider context, which includes our culture and history (the connotative level), that produces the ideological message. Therefore the picture can function on the level of a myth. Representations of the picture are composed of signs with meanings, because these belong to the socially excepted codes that readers recognise

${ }^{2}$ The newspaper was published by the Institute for the advancement of households in Ljubljana, which was established under the auspices of AFŽ (Women's Anti-Fascist Front). It was first released in 1954 and was published regularly until the end of 1960. It represents the most important domestic educational literature so we will take it as an example of educational discourse of the time. 
and decode. According to Bignell (1997: 60) women's magazines create mythical social meanings of femininity. Since meaning is always ambiguous and several conflicting interpretations are possible, the aim of representative practices is fixation of the meaning provided by the text, added next to the image in the magazine advertisement, as it narrows the possibilities of interpretation. Taking this into consideration we need to be mindful of the mutual entanglement discourse of photos and language, which, according to Barthes (1987), enables fixation of meaning.

\section{TECHNOLOGICAL DEVELOPMENT IN SOCIALISM AND THE GRADUAL INTRODUCTION OF WASHING MACHINES INTO HOUSEHOLDS}

One of my informants remembered a scene, when a neighbour's daughter sat next to a washing machine and stared at it with her mouth open: "It is a wonder! What a change!" Mila's husband Jože remembers how he would, time and again, observe the first washing machine as it was washing, and was absolutely impressed. "How it would take the water, washing powder, how it would mix them, and again and again. It was like a plant, like a proper factory." Some of my informants even remembered the celebration at home upon purchasing their first washing machine.

As Spiler (1956: 50-51) points out, we need to understand the arrival of washing machines on the Yugoslav market in a broader context. We must consider other appliances that could be found in the stores in mid 1950s, such as: electric stoves, water heaters, stoves, flat-irons, refrigerators, vacuum cleaners, etc. According to my informants, the first automatic washing machines were considered to be a "technological wonder" compared to those appliances. They came on the market during the period of the most intensive modernisation of the household and increase in family well-being in Yugoslavia between 1961 and 1965, when at least half of the stoves, refrigerators, phones and television sets - considering the total number of appliances sold in the entire Yugoslav history - were purchased (Duda 2005: 65).

Investments and production have increased; not only with regard to devices which facilitate work, but also with regard to cultural goods of technological development and well-being, such as television sets, which enabled people to spend their leisure time a certain way; they were unlike the washing machine, which promised to people that they would save their leisure time. In 1960 more than 2000 washing machines were sold in Slovenia, in 1965 over 9000 , while the sale of washing machines increased the most in the period between 1965 and 1970, when almost 40000 washing machines were sold; also due to the fact that an automatic washing machine 
appeared on the market. It was technologically more advanced than the semi-automatic washing machine, already present on the market. In 1960 the sales of washing machines produced a profit of 2 million dinars, in 1965 14 million, but in the period between 1965 and 1970, a profit of 117 million dinars was reached. The profits with washing machines increased gradually in Slovenia and in 1975 they added up to 182 million dinars (Statistical Yearbook of Socialist Republic of Slovenia, year XV. Ljubljana: Slovenian Institute for Statistics 1976: 310-2).

Observing the statistics regarding the presence of washing machines in Slovenian homes in comparison with some other durable consumer goods in 1968 , we can see that $47.7 \%$ of households owned an electric stove, $41.2 \%$ a refrigerator, $40.0 \%$ a black and white television set, $35.5 \%$ a washing machine and $18.2 \%$ of households owned a car (Rendla 2015: 189). Despite the fact that the number of television sets was growing faster in Slovenian homes than the number of washing machines, ${ }^{3}$ it should be emphasised that Mila and other women pointed out that the washing machine was always at the top of the shopping list.

If we look at the sales of washing machines in the wider European context, we can see that mass ownership of household appliances was also a novelty in the European capitalist countries at the time. ${ }^{4}$ With the development of mass consumption, higher sales of washing machines and their extremely rapid spread during the 1960s and the 1970s, washing machines became a necessity, and people perceived them as paraphernalia of a normal, modern, civilized life. In the 1980s they were already the norm. The washing machine became "an indispensable member of many families", "the last on the list of household appliances that we would consider giving up" and an "irreplaceable helper and ally" as Lipovšek (1991: 52) wrote in his article in the Sodobno gospodinjstvo newspaper. In the Naša žena magazine, an unsigned reader (1984: 5) asked: "Will the obstruction of sales push us back into the 1950 s, when especially women had to endure the torment of washing by

\footnotetext{
${ }^{3}$ In the 1960s and 1970s television sets quickly became a necessity in Slovenian homes. At the end of the 1960s around 200000 television sets were sold in Slovenia; that is one television set per 8 citizens. At the end of the 1970s half a million television sets or 1 television set per 3 citizens were sold (Pušnik 2010: 231). The data about the number of Slovenian households owning television sets and washing machines shows that in $197882.6 \%$ of households owned a television set and $80.1 \%$ owned a washing machine. In $198391.2 \%$ of households owned a television set and 89.8\% a washing machine and in $198898 \%$ of households owned a television set and 95.2\% a washing machine (Rendla 2015: 198).

${ }^{4}$ Western countries did not have a large advantage over Yugoslavia and the Soviet Union in terms of quality and ownership of washing machines. As stated by Redfern (2003: 123), in the late 1950s the price of a washing machine was $125 £$ in England. The first washing machine was Bendix, which was so expensive that the price was not written on the advertisement for the appliance. Its nearest rival Servis twin tub had a price of $95 £$, which was actually the price of a small car. A great decline in prices began in the early 1950s in England. In West Germany in 1955 10\% of the population had electric washing machines. In France in 1954 8\% of individual households had their own washing machine and in 1980 the share was $80 \%$.
} 
hand? And would it not be wise to consider a reduction of the sales taxes for household appliances that are as necessary as bread today?" and encouraged the Gorenje company to produce a large number of washing machines for the domestic market, arguing that modern families and women "do not exist without modern household appliances". ${ }^{5}$

While talking with Mila about the technological development of washing machines and their subsequent improvements, she said: "But I tell you, the first ones were excellent. They were so durable, but nowadays they aren't anymore." Mila's first Candy washing machine was bought in Italy.

That was the most durable one! I had it for 18 years! I mean, the centrifuge was bad. It removed water badly, but it washed well. Later, such washing machines no longer existed. Or irons. He brought it to me from Germany, I still have it at home. I was also very satisfied with the refrigerator. That one was indestructible. Nowadays everything drops dead very fast. It is made for trade so you are forced to buy a new one. This washing machine was my first and last. I had it for 25, 30 years, it was of really high quality.

Instead of representing socialism as technologically underdeveloped and representing a failed project of socialist production, we will focus on the modernization movements in the socialist industrial development. As stated in Pence and Betts (2008: 7), one of the problems of the post-war conceptualisations of modernity is a common tendency to equate modernity with triumphant liberal capitalism. This is an extension of an older Western cold-war logic, ${ }^{6}$ which characterized state socialism "as essentially a culture of surveillance, privation, economic management and colourless lifestyles". The West German critic H. M. Enzensberger (in Pence and Betts 2008: 7) remarked that "real existing socialism" was "the highest stage of underdevelopment". Beilharz (2009: xv) points out that Americanism and Fordism looked like the dominant post-war modernity. "Triumphalist procapitalists after 1989 would of course announce that there was only one modernity, capitalism or more literally Americanism" (Beilharz 2009: xii).

According to Luthar and Pušnik (2010: 11), Yugoslavia was the result of a Western gaze imposing its hegemony on the non-Western periphery in accordance with Yugoslav peripheral position and backwardness. Pence and Bets (2008: 7) argue that the 1989 Eastern Bloc revolutions seem to imply

\footnotetext{
${ }^{5}$ In socialist Yugoslavia there were 17 major companies that produced washing machines. The most well known companies were: Gorenje, Rade Končar and Iskra (Krpić 1989: 47). Gorenje also producedother household appliances and had the biggest profits of all the companies in Slovenia in 1988 and was among the three largest exporters to the Western markets with a 6.6 share in export (Klemenčič 2013: 117-8).

${ }^{6}$ As stated in Kršić (2012: 211), to agree on the division of the West/East, capitalist/socialist, centralist and peripheral, colonial and modernist would mean to agree on the reproduction of the Cold War.
} 
that the very idea of socialism, as judged by the forms of its "neo-absolutist" political world and shabby material culture, was in essence unmodern. Once socialism was removed from modernity, it became easy to reread the events of 1989 as a desire to be modern - Western. The West often serves as a standard for comparison of technological development of the socialist countries. Stokes (2000: 6-7) points out that the comparison of the standards of technological development of Eastern and Western Germany were used exclusively to highlight the differences rather than the similarities between the two countries. Political implications had real consequences, and the construction of a virtual wall in Germany in the 1950s, based on different technological development, led to the construction of a real one (Stokes 2000: 10).

As stated in Kršić (2012: 212), there is no one "right" modernism (Western), according to which all other modernisms are secondary deviations. There are different modernities (Asian, Latin American etc.) and socialisms (Beilharz 2009: xv). Moreover, debates about cultural modernity are mainly focused on the spheres of economics and politics, but we also need to include in our research everyday cultures in areas such as pop culture, consumption, and art. In this way a more complex picture of modernizing Yugoslavia emerges. ${ }^{7}$

Mila especially emphasised that washing machines in socialism were not made simply to increase profit and trade. They were of higher quality and were more durable in comparison to contemporary washing machines, despite some technical imperfections, such as poor centrifuge. Considering their longer time period of use, the machines were cheaper. This did not apply only to socialist production at the time. Mila imported her washing machine, electric iron and refrigerator, all of which she described as indestructible, from capitalist Western Germany. Her first washing machine was bought in capitalist Italy. According to her narration, the quality and indestructibility also related to products of capitalist production at the time. This notion draws attention to the fact that the capitalist system is not a static one, since the one Mila spoke of differs from the capitalism we know today. For this reason, every socio-political system needs to be understood in the context of its time.

\footnotetext{
${ }^{7}$ For example, Kolešnik (2012: 130-2) says that creating abstract art on the Yugoslav cultural scene is a confirmation of a true deviation from the totalitarian doctrine of Socialist Realism, which brought the Yugoslav world closer to the ethos of the "free world". Abstract art followed a vision of modernity with "clean" stylistic forms, accompanied by the same types of discussions as in the other European countries at the time. For understanding the problem of modernity as a special configuration in the popular culture while researching elitism of modernistic exclusivity and democratisation of popular inclusivity see Senjković (2008) and for information about the emerging new middle class in Yugoslavia, which was shaped by the socialist modernization process and consumption, see Luthar (2006).
} 
Rational consumption in socialism was associated with the life span of products, their functionality and standardisation and with long-term solutions. We can agree with Zsuza Gille (2007), who challenges representations of socialism as wasteful, considering it produced too much excessive garbage and obsolete goods, as opposed to representations of purity, effectiveness and frugality of Western capitalism. The question of socialist wastefulness carries political implications in the context of constructing socialism and capitalism, or as Gille (2007: 13) points out:

Waste plays different roles in constituting what we refer to in a rather objectifies manner as "socialism" and "capitalism" [...] Waste is not only a representational perspective [...] but also a constitutive element of the social orders.

We must understand wastefulness as a constitutive element of social order and its material economy, since waste and society mutually constitute each other (Gille 2007: 13).

When washing machines are sold today, their efficiency in the consumption of power, water and washing powder is emphasised. A lower noise level of the washing machine is also emphasised, as is the fact that it spin dries more effectively, washes quickly and is easy to use. Environmental friendliness is also pointed out in the advertisements. What changed significantly from the past is that consumers now have a much greater choice of models. However, Mila owned only two washing machines in her entire life. The first one was the Italian Candy and the second one, which she bought three years before moving into the home for the elderly, was made by the Slovenian company Gorenje.

Mila remembered that her colleague told her: "You should pay attention to everything, how much electricity it consumes, all of this", but she told me that these things never mattered to her. Mila used only one washing machine nearly her entire life. She did not replace it when new types arrived on the market, nor was she interested in their technological improvements. When she bought the first Italian washing machine, Mila did not think about its economy, but was mostly interested in who of her acquaintances would help her with the purchase and how long she would have to save for it.

\section{LAUNDRY WASHING AS A PART OF WOMEN'S WORK IN THE HOUSEHOLD}

When I asked Mila and her husband Jože who did the laundry in their household, Jože firmly answered "both of us", whereas Mila started laughing and shaking her head and told me the following anecdote: 
You know, when I was in the hospital, Jože was washing his underwear. Yes, but he put a red T-shirt into the washing machine together with a white pair of underwear and it got pink! Girls that dress us here in the elderly home were making fun of it and said that this underwear must be mine, since it is dyed pink. I told them: "No, Jože dyed it pink."

By telling me this, she indirectly told me that she was the one really skilled to do the laundry in their household. While listening to the other women I got the impression that they did the laundry in their household by themselves because they were often convinced that they are simply better at this household chore than their men.

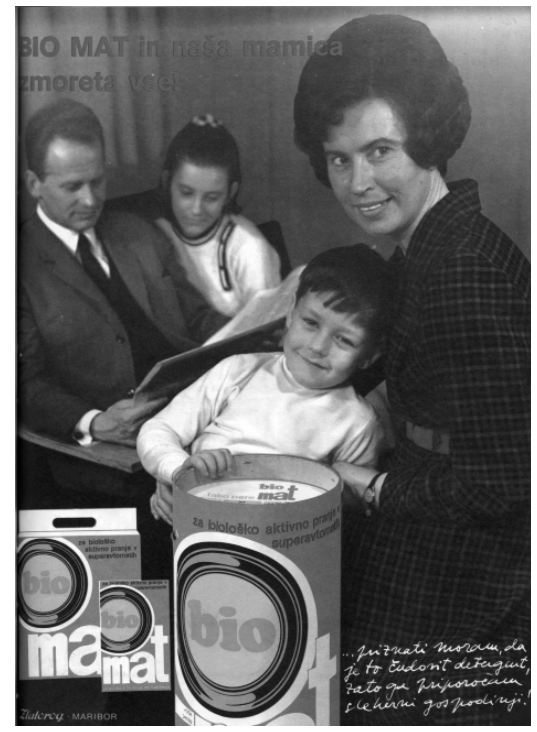

Figure 1. Bio Mat and our mother can do anything! Tovariš 1969, no. 25(2).

Common advertising motifs of a socialist life depicted positive images of collective joy and socialising, happy employed women and cheerful families. The picture above depicts a family of four. The father is sitting in the back, reading a newspaper and not paying attention to the world around him. He is wearing a tie and is dressed in his formal suit. The mother is sitting in the front wearing a simple and tidy dress. In her arms she is holding a boy who is holding a washing powder, and the commercial slogan above is communicating to us that his mom can do anything with its help. Although we can discern emancipatory potential in the sentence "our mother can do anything", this positive charge wanes when we understand it in the context of the whole advertisement, which communicates that the woman is doing the housework and is being helped by the new washing powder and not by her husband. 


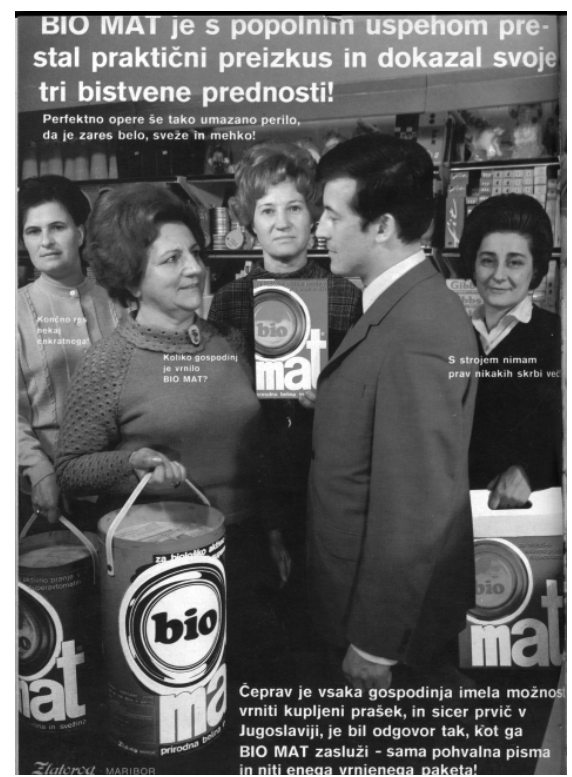

Figure 2. Bio Mat. Tovariš 1969, no. 41.

The picture above depicts four tidy middle-aged housewives holding washing powder packages. Three of them are looking directly at us and one is attentively staring at a man who is teaching her about the washing powder. The caption says: "Although every housewife had a chance to return the washing powder she bought..." This advertisement shows that the laundry was done by the women, whereas the man is portrayed as a teacher who provided help to the women in doing "their" task.

Advertisements for washing machines and washing powders address women and the family. Men are not the main targets of the advertisements and although they are present in the role of advisers or fathers, there is always a woman present, who is portrayed as the main target of the advertisement. The photographs and the texts reflect patriarchal relationships, because the woman is always portrayed as the one who is doing the laundry. As Patterson (2011: 91) puts it, household devices provide women with liberation in their role of modern Yugoslav women but not emancipation from this role.

Public services in socialism, such as laundrettes, were primarily understood as relief for the woman from her duties and less as a form of help for the whole family (Jeraj 2005: 282). According to Jambrešić-Kirin (2013: 189) the expectations for women to do the housework and take care of the children remained present in the Yugoslav society despite their full-time jobs. AFŽ campaigns established a goal to change awareness regarding the social roles of women and did not address men - fathers, co-workers and husbands. However, the emancipation of women requires policies that strive 
to change the balance of the relationship between both genders in the society as a whole (Einhorn 1993: 35-6; also see Bourdieu 2010).

Today, Mila and my other informants observe life changes over time through their children, grandchildren, other relatives and employees in the home for the elderly. Through their children, the informants experienced a generational change in the upbringing of children and doing housework and they believe that things are improving, because today men are also included in these tasks. Mila was pleasantly surprised, because she noticed that plenty of men today know how to cook and how to do the laundry. "In the past a man was henpecked if he did housework, because this was women's work. It was different back then." Other informants proudly told me that they raised their sons to participate in the housework and in this way contributed to gender equality through their roles as mothers. My informants do not express any desire to return to the previous time; on the contrary, they seem to observe important shifts for the better in the division of labour between men and women in the household of the contemporary society. They pointed out a generational leap and stressed that they were raised in the spirit of strict gender division of labour.

The introduction of the washing machine into the household changed communication within the family, life patterns, expectations and ways in which the family operated. According to Mila's narration, the division of housework remained gendered. In addition to working full time jobs, to which, according to Blagaić and Jambrešić (2013: 46), women's emancipation owes much more than to their modest participation in the political life, an entire generation of women still remained responsible for cooking, cleaning, doing the laundry and raising the children in their households (Dobnikar, quoted in Kollontaj 1982: 11; also see Einhorn 1993; Gail and Kligman 2000; Pence 2008; Verdery 1994; Cowan Schwartz 1983). However, we argue that the washing machine as a new piece of technology brought an important shift to the understanding of the division of labour between men and women in the household.

Today the assumption that gender is socially constructed dominates in cultural anthropology (see Geertz 1975; Mead 1962; Nanda 1999; Haraway 2001, 2004 et. al.). As stated in Game and Pringle (1984), technology and masculinity are closely related. In this article we follow the assumption that there is nothing inherently or naturally masculine about technology. The idea of women's exotic attitude towards technology derives from historical Western tendencies of the $20^{\text {th }}$ century perception of technology as an exclusively male affair. In our research into the connection between gender and technology we will follow the assumption that technology is formed in a particular society and therefore social patterns between genders are reproduced, while at the same time technology shapes society and reinforces gender divisions in the society (Frank et al. 2006). 
Stereotypically, we ascribe the responsibility for household tasks connected with technology to men, such as the maintenance of cars and home repairs, and non-technology-related tasks to women, including cooking and child care. Franklin (1999: 24) points out that when certain technologies and tools are used mostly by men, masculinity becomes a part of the definition of these technologies. Because a certain technology represents identification with male gender, it can lead to an exclusive use of technology. There was an unsigned article published in the Sodobno gospodinjstvo newspaper in 1959, indicating that it is understandable that the standpoint of women towards machines is different from that of men, since throughout the past centuries women had performed housework tasks by hand, which is why they had difficulties in adapting to a different way of doing things. Men observe technological developments in a manner completely different from women, which is why it is easier for them to get excited about such developments.

While talking with my informants about who did the laundry in the household, Mila told me that men would also do the laundry, since they at least turned the machine on or off. Mila said that Jože would help with the laundry if she was occupied with other work. She sent him to check if the washing machine would soon finish. While Mila and Jože both turned the washing machine on and off by pressing the appropriate button, Jože was the one who was more familiar with the washing machine as a piece of technology. Also, washing machine repairmen were usually male. Mila remembered: "When we got the washing machine, I said: "Jože, sit down, read and study all this and let me know which buttons do what, where to switch it on, where to turn on the centrifuge... I wasn't about to read that."

The article also states that the generation of young women "will certainly look on these things as they should" which denotes that a change has occurred in the perception of the relationship towards technical goods between genders. Furthermore, we can also read that before buying a household appliance, the housewife should educate herself about it.

It is not enough for her to understand all the instructions, she must also expand her technical knowledge. The rapid development of technology and technological advancements in household machines requires the housewife to be able to discuss and consult with the salesman and the repairman in a professional manner. (Anon. 1959: 245)

Only by understanding the machine from a technological point of view would a woman be able to use it efficiently.

As opposed to non-mechanical hand washing, with the introduction of the washing machines into the household we can notice that men started participating in doing the laundry for the first time. Precisely because of 
the stereotypical relationship between the male gender and technology, technological development began to gradually include men in household tasks. Technological development transformed households from basic productive units into consumable ones. Magazines and newspapers presented the standard of good taste in decorating one's home, which was based on the imperatives of modernist simplicity and functionality. It represented the symbol of good taste of the housewife and her personal happiness.

With the introduction of new household technologies, domestic work became not only "modernized", but also more emotionally involving and "aesthetic", in the sense that the standards also included style, harmony and atmosphere. Through their household, women were now expressing their own personality and became administrators in their home (Lury 1996: 127). By buying and using modern household appliances, such as the washing machine, women became domestic agents of modernisation with the mission of transforming other family members into modern citizens (see Chernyshova 2013; Reid 2007).

The washing machine had emancipatory potential, because it promised a reduction of the amount of housework in the household. However, due to the prevalence of washing machines and their easy availability to many individual households, the majority of women washed clothes at home rather than in public laundries, since the mass consumption of washing machines and irons enabled them to do so (see Bowden and Offer 1996: 245). Besides, the process of the transition of washing from the private to the public sphere in the form of laundrettes ${ }^{8}$ was not always received approvingly by women. As noted in Tomšič (1958: 67):

We took a look at the first stages of residential communities in Ljubljana and discovered that some services will have great difficulties with regard to functionality, because women are resisting the idea of other women coming to their house to perform their tasks. In many places women drop out and no longer want to wash using the common washing machine.

However, an article from 1960 from the Sodobno gospodinjstvo newspaper indicates that washing in laundrettes was a great relief for women and that it was also not considered to be particularly expensive. Moreover, laundries employed women, who thus had an additional source of income (rž 1960).

${ }^{8}$ As stated in Povoden (1955: 58-61), in 1955 there were different laundrettes available in socialist Slovenia. One type, "the lease", was a laundrette where women brought their laundry and washed it in machines by themselves under expert guidance. In "craft laundrettes" laundry was washed, dried and ironed by professional staff. In smaller laundrettes one could find small machines that washed up to 8 kilos of laundry at a time. Washing was done in a single day and then delivered to customers. In large laundrettes, machines were bigger, there was better organisation of laundry delivery, they had better machines because of their size and were suitable only for settlements with over 30000 inhabitants. 
The failure of public laundries gives rise to scepticism about the "hard collectivism" both in the country as well as the city, as we can see that socialist citizens were also seeking to obtain the values of individualism and family sphere, which guaranteed them safety, hygiene and intimacy. With the emergence and increased accessibility of washing machines, the chore of doing the laundry returned back into the unpaid private sphere. The return of washing the laundry back home affirmed women's roles as consumers of individual products instead of shared public services.

The period of the introduction of household appliances in the socialist as well as the capitalist context is connected with the construction of masculinity and technology as reflected in the participation of men in the process of washing using the washing machine. Advertising discourse and my informants' narratives confirm that men retained the roles of instructors, repairmen and supervisors and did not share household tasks with women. The fact that modern household appliances helped women to develop new aesthetic and affective politics of self-realisation as exemplary modern housekeepers, mothers and wives is not reflected in the narratives. This leads us to believe that they were aware of many economic and social constraints that were preventing their full emancipation and that they only consider their daughters and granddaughters as emancipated women.

\section{TIME SAVED WITH THE USE OF A WASHING MACHINE AND ITS RELOCATION}

When Mila talked about her leisure time, she often stated that she suffered from a lack of it. Like many of my informants, today Mila lives in a home for the elderly in Ljubljana, where other people are taking care of her and her husband, so she has more time to do the things that she wanted to do in the past, but could not find the time for. Mila was born in 1927 as an only child in a working-class family. She found employment with the municipality of Ljubljana where she remained until her retirement. After marrying in 1955, when she was 29 years old, she built a house with her husband and gave birth to one son. When I asked her about her leisure time in the period when she was employed and had a small child, she waved her hand: "Leisure time? There was no leisure time." In addition to going to work every day, she also attended evening school, took care of the household, attented meetings of the Party. "There was not enough sleep. That is why I got tuberculousis. Well, you survive everything."

Alenka, a textile worker, born in 1935 in the countryside near Celje, had six children and she said that in her leisure time she loved to read books and 
watch movies and added: "There was not a lot of leisure time. To me, time was precious. I had so much housework to do - six children! I could not sit and watch television, because I could not make up for the lost time." Women like Mila and Alenka were the ones who mainly dealt with the consequences of economic problems of the socialist system in socialist Slovenia, especially with shortages. They were the ones who used their time off work for grocery shopping and doing things for other family members.

Modernisation, introduced with washing machines, is connected with monetary economy. According to Adam (1995: 100) being effective means performing the task in the shortest possible time, while being profitable means spending as little money as possible during working hours. In the household, the goal of mechanisation and innovation is not to enable the production of a more useful value in a given amount of time, but to reduce the time spent on a given activity.

Time and energy spent in activities such as cooking, babysitting, washing and mending clothes, are impossible to measure objectively. Time spent for housework, which is located outside the clock time of employment relations, is understood in relation to the economic principles of profit of commoditised time (Adam 1995: 95). It operates according to non-economic principles, because it can not be placed on a schedule, nor can it be attributed monetary value. If we refer to Schor (1992), precisely because the economic value of the time of a housewife is unrecognised and because the leisure time of women is assigned a low value, the ownership of household appliances, such as washing machine, could be understood as saving.

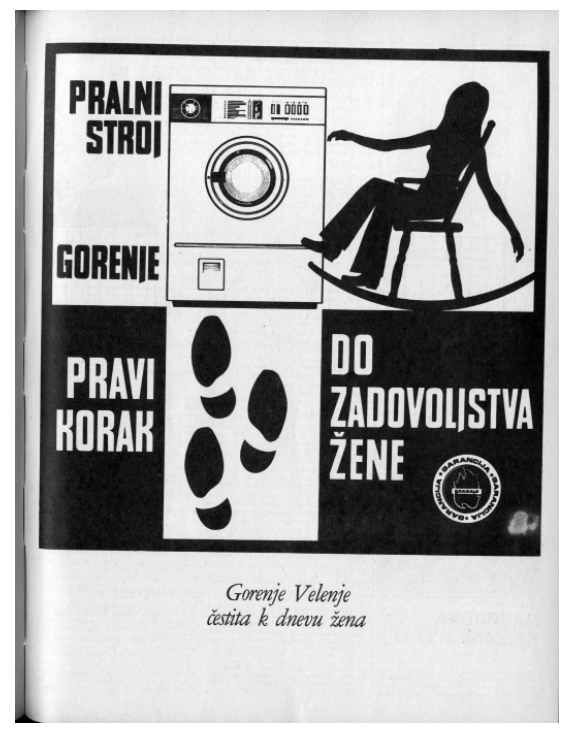

Figure 3. The right step towards a woman's satisfaction. Naša žena, April 1974. 
How were women like Mila directed by public discourse to use their newly saved time? In Figure 3 we can observe a Gorenje advertisement, where the washing machine company communicates to men that buying a washing machine is the right step towards a woman's satisfaction. Next to the text there is a drawing of a woman, sitting in a rocking chair. This signifies that the woman has more leisure time during which she can rest, as the washing machine washes instead of her. The advertisements for washing machines show emancipatory potential, since they promise satisfaction and more free time to women; time, which could be used for rest.

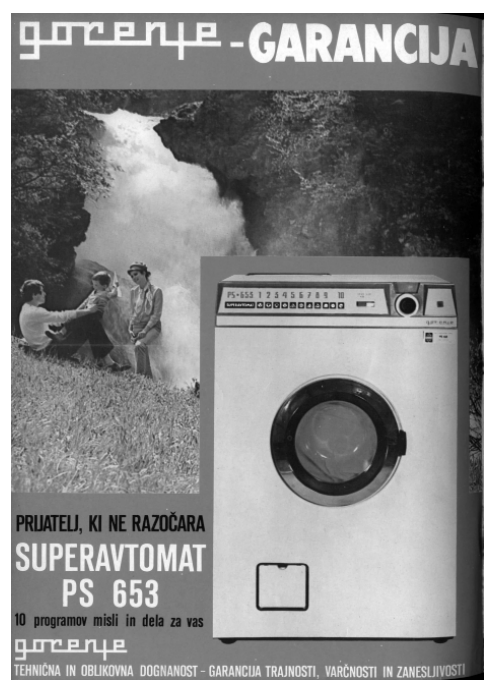

Figure 4. A friend that does not let you down. Tovariš 1969, no. 42.

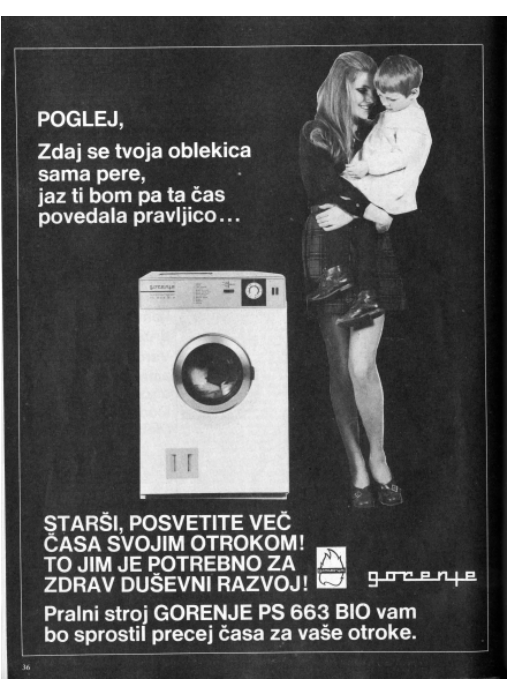

Figure 5. Parents, dedicate more time to your children! Naša žena, April 1974.

In Figure 4 a Gorenje washing machine is advertised as a family "friend that does not let you down". By using this slogan the company was referring to the quality and reliability of the product. Gorenje's new washing machines were characterised by a reduced consumption of water, detergent and electricity. Their technological progress provided shorter washing time thus promising more free time for its users. ${ }^{9}$ We can observe a three-member family in the background. The mother is leaning over her family and the father is playing with their son. This advertisement says that the washing machine promised women more leisure time, which they could spend with their family in the nature.

\footnotetext{
${ }^{9}$ Later machines could wash four and a half kilograms of laundry, whereas the first automatic machines could only wash four. Washing time was also reduced because more recent types of washing machines washed faster, in 97 minutes, whereas the first automatic machine took 150 minutes for its task (Lipovšek 1991: 52).
} 
In Figure 5 we see a young mother, holding a child in her lap. The text conveys a message that while the laundry is being washed on its own, the mother can spend more time with her child and take better care of his upbringing. Even if the washing machine enabled a faster and more efficient washing of clothes, the amount of time, used for raising and looking after a child is not flexible and could not be shortened because it lasts all day. What seemed at first glance to be women's leisure time was actually often a form of caring for family members.

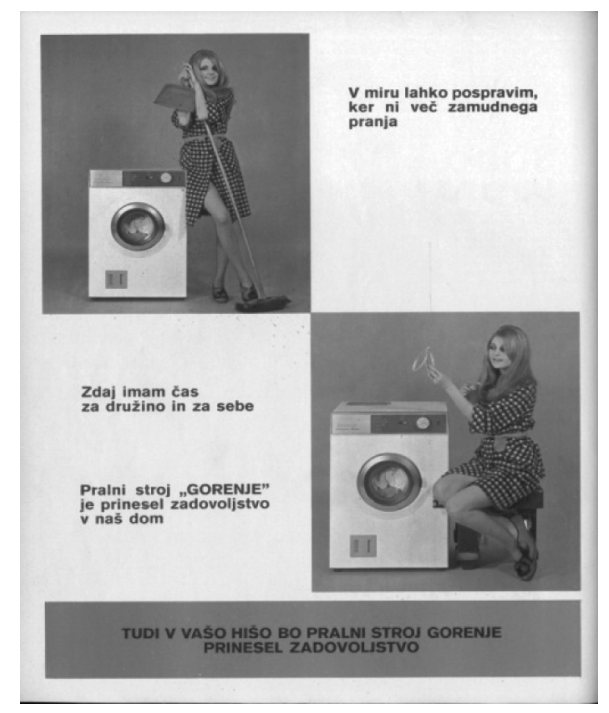

Figure 6. The Gorenje washing machine will bring satisfaction into your house as well. Tovariš 1970, no. 26(4).

In Figure 6, the image at the top shows a beautiful young girl holding a broom and a dustpan. She is letting us know: "I can clean in peace because there is no more time-consuming washing." In the second photograph she is saying that due to the purchase of a washing machine she has more time for herself. By looking in the mirror and combing her hair she is now dedicating more time to her appearance. The advertisement conveys the message that a woman needs to be a good housewife by taking care of the family and devoting her leisure time to "cultivate physical attractiveness" through the use of cosmetics, fashionable dresses and hairstyles, jewellery and other "attributes of femininity" (Reid 2007: 59).

The network of social facilities, such as laundrettes and household services, were regarded as a way to relieve women of housework and to promote equality (Beltram 1956: 67) and, according to Jogan (1986: 51), also a way to enable conscious demolition of the material and moral foundations 
of the patriarchal family. It was predicted that by abolishing the individual household, which burdens women with caring for the family, women would become a part of the social production and have more free time to engage in public life (Tomšič 1955: 2). The mechanisation of washing laundry in public laundrettes served to facilitate "women's household tasks in their free time, so they would not come to their work places exhausted" (A. 1956: 76), which allows us to observe the persistence of the discourse about housework as "women's work" that they perform in their free time.

The public discourse of the Sodobno gospodinjstvo newspaper in the 1950 s advised women to use the newly-gained time to participate in public life as equal citizens, to improve their education and qualifications for their jobs in order to achieve full social equality and also to pay attention to the education and upbringing of their children. However, according to the analysed advertisements we can observe that the public discourse changed in the 1970s, since it dictated to women to use the time saved by the washing machine to achieve higher standards of cleanliness in their home and to relocate their saved time to the loving aspects of the household and use it for cooking more delicious meals, providing better care for children and improving their appearance.

The socialist standards of cleanliness and upbringing have risen significantly in the period from 1920 to 1960, thus women remained more occupied since the spared work was diverted to other tasks (Lupton 1993). American researcher Cowan Schwartz (1983: 214) points out that we need to rethink the unwritten rules

to change our sheets once a week and keep our sinks spotless and greaseless, to wipe the table after every meal, to flush the toilet, brush our teeth, change our clothes and wash our hair, to give music lessons to our children and keep our dirty linen literally and figuratively to ourselves - generate more housework than may really be necessary. (Cowan Schwartz 1983: 214)

We have inherited rules from the older generation of our parents and the rules themselves originated from the fear of general lack, generated by poverty, and a desire to rise above it (Cowan Schwartz 1983: 214).

Oakley (2000: 110-112) provides us with similar findings when she says that due to automation and general improvement of the living conditions, housewives today do not spend less time on housekeeping than their mothers or grandmothers, because women themselves seek to raise the criteria and improve their everyday tasks. Those tasks that have been covered by household appliances and do not need to be performed anymore have been replaced by new and more complex duties. The way of doing housework and the criteria for the achievement of standards are transmitted from generation 
to generation through general socialisation, whereby the mother teaches the daughter about housekeeping and identification with her work alongside other influences such as school, television, media press etc.

The washing machine had the potential of a significant reduction of time spent for washing. However, this did not automatically mean more leisure time for modern housewives. Clothes were washed more frequently and they had to be cleaner. Mila told me that she usually washed clothes twice to make sure that they were "really truly clean", pointing to a high standard of cleanliness. The washing machine as a new piece of technology in the home challenged and weakened the strict division of labour between men and women to a certain extent and greatly reduced the workload of women, burdened with hand washing. However, the time spent on washing, actually increased for some women because they were expected to wash clothes daily, not weekly.

Figure 7 depicts an advertisement for a Gorenje washing machine. We can see a seductive girl playfully lifting her white skirt. White symbolises cleanliness that the washing machine enables.

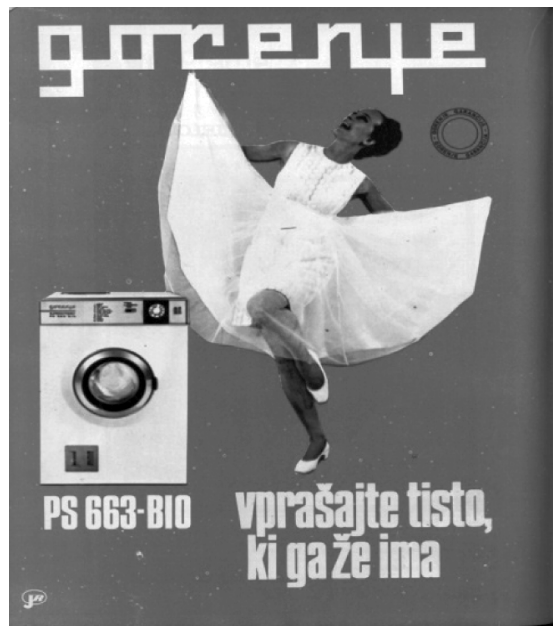

Figure 7. Ask the one who already has it. Tovariš 1970, no. 37.

Meta, a friend of Mila's, also lived in the home for the elderly, where she occasionally joined us for a cup of coffee. She was born in 1928 in Domžale near Ljubljana. At the age of 38 she moved to Ljubljana where she lived alone in her apartment since she did not have any children. On one occasion we talked about the aspiration for immaculate whiteness of the laundry. Meta remembered: "If it wasn't washed properly, it looked brownish. This was not beautifully washed laundry. Dull lanudry. When Jože washed the laundry it 
was dull." The ultimate goal of washing is clean spotless laundry, symbolised by the ideal of snow-whiteness, which represented the standard of cleanliness to aspire to even before WW2. ${ }^{10}$ Mila remembered that her mother put the laundry on clean grass and when it was still wet, spread it out so that the sun shined on it and thus whitened it. In Meta's family they washed the laundry by hand with ashes of beech wood to achieve whiteness. "That was so nice, beautiful white laundry that you could barely believe it, and it smelled so nice. There was such a smell and whiteness."

The understanding of standards of cleanliness was closely linked with the values related to the concern for loved ones. In the 1950s, the concept of cleanliness and hygiene was connected with the valuation of socialist progress. Tomšič (1954: 99-100) emphasised that it is necessary to fight against everyday scourges, such as backwardness and unhygienic habits "because we know very well that there is no socialism and communism where people live in filth and ignorance".

Both Mila and Meta agreed that mothers were measured by the cleanliness of their children's clothes. Meta recalled: "Neglectful, they said, this is a neglectful mother if she lets her children go out into the street looking like that." Meta remembered that her mother often said to her and her sisters: "You better always be clean and washed, especially mind your underwear." When I asked Mila whether she allowed her son to go to school with a stain on his clothes, she gave me a horrified look. "Oh no, no way he would wear something like that. At home, yes, and to go to the garden, but to go somewhere else, no way. No, I would find him neglected." And this is something that she as a good and exemplary mother to her child could never allow herself.

"Cleanliness" is, as pointed out by de Regt (2009: 148), a key element of housework, which applies not only to the actual act of cleaning, but also to the person who cleans. Meta and Mila were brought up in working families that valued neatness and cleanliness higher than the middle class. As stated in Kohn (1989: 23-4), the children of the working class, especially girls, are dressed in a cleaner and tidier manner, even at home, unlike the girls of the middle class who do not wear clean clothes at home as much.

Meta pointed to yet another important thing when she remembered that in the period of hand washing the differences between families in terms of cleanliness of clothes were much bigger. They said: "She has such clean laundry. Hand washed laundry had to be boiled in the electric pot, but not

\footnotetext{
${ }^{10}$ In the advertisement for the Radion washing powder from 1937 we read: "The laundry is protected and it becomes snow-white ..." The advertisement is located in a booklet entitled Our home: how to built it (2nd and 3rd book), the author is Rado Kregar.
} 
all women did that. That was not the case with the washing machine." In this context we can perceive the washing machine not only as a household appliance that relieved women of the difficult physical work in the form of hand washing, but also as a gadget, which unsettled the relationship between social position and the criteria of cleanliness, which could now rank only as high as they could be achieved by the washing machine or washing powder and were not measured by the zeal of a woman rubbing the laundry by hand. By doing laundry with a washing machine, women of the working class no longer needed to strive to exceed the standards of cleanliness of the middle class in order to achieve a sense of self-esteem, since the women of the upper class also washed their laundry using a washing machine.

The washing machine can also be seen as an object which enabled the creation of differences among people and contributed to the stratification of society. As Marta remembered: "Well, if the neighbour had a washing machine, this was of great importance, she was superior. There was much more envy. Oh, they have a washing machine and also a car - and what a car!" According to Mila, social stratification existed within Yugoslavia as well, as Slovenian women were the first to get the washing machine.

It was precisely the problem of vertical stratification of the population that led to increased tension in the Yugoslav society. An increase in the production of household appliances led to more evident differentiation among consumers. By purchasing expensive goods, such as washing machines when they entered the market, people began to be divided into those who could afford it, and those who could not, as described in Drakulić (1992: 49), who says that the high price of washing machines was an additional reason for people to buy them because in this way they demonstrated that they earned enough money. However, in the course of time, washing machines became affordable for people with less money, who could buy refrigerators, stoves and washing machines; but at the same time individuals in better social-economic situations would already be buying cars and building houses because they already had other household appliances (Ilić 1984: 151-2).

How did women such as Mila and Meta experience changes in their leisure time due to the washing machine? When I asked them about their use of the newly acquired leisure time that the washing machine provided, Mila shrugged her shoulders and remembered:

You know what, I had new obligations. My mother was very sick, my aunt was very sick and then they called. I had to go home very often. Do not think I had much spare time. I was living outside of Ljubljana and had to ride my bicycle to work or I came by train. The washing machine saved little time, but since you had time, you started performing other tasks; this is what I still need to do, oh, and that is still waiting for me. 
While listening to Mila, Meta was shaking her head as a sign of disapproval: "Yeah, well, but while the washing machine was washing, I could sit nicely in front of the television or, if somebody came to visit me, talk to them." Mila raised her hand and stretched her forefinger to point out that she has something very important to say: "Well, but maybe... Those worries, oh no, I have clothes, sodden in water and this is what I still need to wash by hands... They were gone. You just threw the clothes inside and waited for the washing machine to do it. This was such a relief. Really." Meta recalled: "They said back then that you could leave it. You could just turn on the machine and walk away." Mila was looking at Meta in amazement: "I didn't dare to leave it, I was afraid, you know." "Well, I left it and everything worked well every time" replied Meta.

It is true that washing machines took away the burden of the most difficult tasks and concerns of women, but at the same time Mila, being a married woman with one child, used this time to carry out other housework tasks. The amount of time Mila used for housework remained the same since she was performing other housework tasks while the laundry was being washed (see Duda 2010: 201; Orehovec 1997). On the other hand, Meta, who lived alone and did not have a family, enjoyed this newly saved time as leisure time. The official discourse encouraged women to spend their newly-obtained leisure time to improve their own household, their appearance and motherly role, but women interpreted those discourses in their own way and spent their leisure time in different ways.

The way they spent their leisure time says a lot about the social and economic conditions of the system, but limitations and opportunities of leisure activities also depended on personal preferences and socio-economic status, including whether the woman was employed and married. The notion of "leisure activities" is relative in both the capitalist and socialist context and coded according to gender, profession, socio-economic status, education, marital status and personal preferences.

While washing machines were often depicted as domestic servants in advertising campaigns, new household devices never promised full replacement of extra work, and washing was never meant to become a task performed entirely by machines (Bowden and Offer 1996: 267). As we can read in the Sodobno gospodinjstvo newspaper in the article "The modern household" from 1959, the automation of further work, such as ironing, hanging and collecting clothes, is unimaginable, but women should not be too sad, because "they would not want to leave the setting of the table, watering the flowers and helping children with writing, learning and doing homework to machines" (Anon. 1959: 243-4).

In the public discourse housework was connected with loving one's children and with the joy of arranging one's home. Women were specialised 
for providing emotional support to their family members and for giving love to them, because in mid $20^{\text {th }}$ century, housework became an expression of love and warmth (see Hrženjak 2007; Lury 1996; Šadl 2002). According to Game and Pringle (1984: 127) doing the laundry became an expression of love, cooking and cleaning a mode of "making home" and a style of artistic expression and also promotion of family loyalty. Changing diapers became a filthy pleasure and a way of building a child's sense of security and love towards his mother; brushing the toilet became not only cleaning, but also a mother's defence of her family against diseases.

\section{CONCLUSION}

In conclusion, according to Mila's narration, the housework division remained gendered and her generation of women mainly remained responsible for cooking, cleaning, doing the laundry and raising children in their households. However, the washing machine as a new piece of technology brought an important shift in the understanding of the division of labour between men and women in the household. Unlike with non-mechanical hand washing, with the introduction of the washing machine into the household one can notice men's participation in doing the laundry for the first time, precisely because of the stereotypical relationship between the men and technology. In any case, it must be emphasized that although the washing machine introduced men to the world of housework and obligations, this by no means meant an actual weakening of gender roles and gender stereotypes in society.

The modernisation process after WW2, especially from the mid-1950s to mid-1980s unified and equalized the lives of citizens to a greater extent than the political experience of a life in competing ideological blocs. According to the analysed advertisements, public discourse dictated that women should use the time saved by the washing machine to achieve higher standards of cleanliness in their home and to relocate their saved time to the loving aspects of the household and use it for cooking more delicious meals, providing better care for children and improving their appearance. The washing machine as a new piece of technology in the home challenged and weakened the strict division of labour between men and women to a certain extent and greatly reduced women's workload. However, this did not automatically mean more leisure time for modern housewives.

The amount of time Mila used for housework remained more or less the same since she was performing other housework as the laundry was being washed. Sometimes the time spent on washing actually increased for some women because clothes were washed more frequently and they had to be cleaner, since the ultimate goal of washing was clean, spotless laundry, 
symbolised by the ideal of the snow-white colour. In spite of the fact that the official discourse encouraged women to spend their newly-obtained leisure time to improve their own household, their appearance and motherly role, women interpreted those discourses in their own way and spent their leisure time in different ways, according to their personal preferences and socio-economic status.

Mila looked at me as a representative of the younger generation and I recognised a kind of disappointment and anger in her voice while she was shaking her head:

Nowadays you have it all, many doctors, a washing machine, even a dryer, a bunch of stores right under your nose. This is a kingdom in comparison to what we had at the beginning. And not only this. Now you have Pampers diapers. I am not sure these young mothers would be able to manage it. How much we used to wash by hand!

She was also critical of the modern way of washing as done by the younger generations, who, in her opinion, wash quite carelessly. "You knew back than you need to sort out linen, put it in the washing machine and soak it. You knew that it had to be soaped and rubbed. Today they often carelessly throw everything into the washing machine." She recalled how she got reusable Tetra cotton diapers from Czechoslovakia but her daughter-in-law was using Pampers disposable diapers. "I told my daughter-in-law: 'Are you going to put those on your child? Come on, a Tetra diaper is boiled and ironed.' I ironed everything for my son. 'No', said the daughter-in-law, 'Not anymore'. I told her she can use Tetra diapers, but she said: 'Oh, come on, who is going to wash them?'” However, Meta said to Mila: "Those times are coming back. Children will have washable diapers again" and it sounded like she wanted to say that younger generations will finally came to their senses and realise that the old ways were better.

Vodopivec (2007: 113) points out that older pensioners shape their memory of the socialist past according to modern social frameworks and political interpretations of the previous regime while focusing on everyday problems and satisfactions. Mila proudly told me she boiled all the diapers for her son and ironed them and thus disinfected them. She invested more time and effort in this way, but she also received confirmation of being a good mother, since this was in accordance with the norm and expectations of her generation. However, this is not the case for her daughter-in-law, whose life is facilitated by Pampers diapers, and Mila doubts that young mothers would be able to survive without them.

Mila belongs to the post-war generation of women, who lived in difficult circumstances. She fought for the freedom of the territory in the partisans 
fighting against the occupying forces with great courage and sacrifices. In the period of the post-war scarcity her generation built a new country, enabled social progress and put much effort into the economical recovery of the country. Today, informants such as Mila legitimize their position to the younger generations by talking about their difficult life in the past, from which they did not emerge as victims, but as more courageous and stronger women, believing that because of everything they survived and sacrificed, they deserve respect and gratitude. Mila establishes her expectations towards others on the basis of her memory. This kind of memory represents a strategy for informants to construct their selves in the modern world and provide the means to position themselves in it.

\section{REFERENCES AND SOURCES}

Abu-Lughod, Lila. 1990. "The Romance of Resistance. Tracing Transformations of Power through Bedouin Women". American Ethnologist 17/1: 41-55.

Adam, Barbara. 1995. Timewatch. The Social Analysis of Time. Cambridge: Polity Press.

A. J. 1956. “Perilo - operi se!” Sodobno gospodinjstvo 29-30: 75-6.

Bartes, Roland. 1971. Književnost, mitologija, semiologija. Beograd: Nolit.

Barthes, Roland. 1987. "Rhetoric of the Image". In Image, Music, Text. Roland Barthes and Stephen Heath, eds. London: Fontana Press, 32-52.

Barthes, Roland. [1957] 2000. Mythologies. London: Vintage.

Beilharz, Peter. 2009. Socialism and Modernity. Minneapolis, London: University of Minnesota Press.

Beltram, Živa. 1956. "Reforma obvezne šole in pouk gospodinjstva". Sodobno gospodinjstvo 29-30: 66-67.

Bignell, Jonathan. 1997. Media Semiotics. An Introduction. Manchester, New York: Manchester University Press.

Blagaić, Marina and Renata Jambrešić Kirin. 2013. "The Ambivalence of Socialist Working Women's Heritage. A Case Study of the Jugoplastika Factory". Narodna umjetnost 50/1: 40-73.

Bourdieu, Pierre. 2010. Moška dominacija. Ljubljana: Sophia.

Bowden, Sue and Avner Offer. 1996. "The Technological Revolution That Never Was. Gender, Class, and the Diffusion of Household Appliances in Interwar England". In The Sex of Things. Gender and Consumption in Historical Perspective. Victoria de Grazia and Ellen Furlough, eds. Berkeley, Los Angeles: University of California Press, 244-70.

Brumen, Borut and Rajko Muršič. 1999. "Uvod v odčaranje tranzicije”. In Cultural Processes and Transformations in Transition of the Central and Eastern European Post-communist Countries - Etnološka stičišča 9. Borut Brumen and Rajko Muršič, eds. Ljubljana: Oddelek za etnologijo in kulturno antropologijo, Filozofska fakulteta, 7-12.

Chernyshova, Natalya. 2013. Soviet Consumer Culture in the Brezhnev Era. London, New York: Routledge. 
Cowan, Ruth Schwartz. 1983. More Work for Mother. The Ironies of Household Technology from the Open Hearth to the Microwave. New York: Basic Books.

Dijanić, Dijana, Mirka Merunka-Golubić, Iva Niemčić and Dijana Stanić, eds. 2004. Ženski biografski leksikon. Sjećanje žena na život u socijalizmu. Zagreb: Centar za ženske študije.

Drakulić, Slavenka. 1992. Kako smo preživeli komunizem in se celo smejali. Maribor: Rotis.

Duda, Igor. 2005. U potrazi za blagostanjem. O povijesti dokolice i potrošačkog društva u Hrvatskoj 1950-ih i 1960-ih. Zagreb: Srednja Europa.

Duda, Igor. 2010. Pronađeno blagostanje. Svakodnevni život i potrošačka kultura u Hrvatskoj 1970-ih i 1980-ih. Zagreb: Srednja Europa.

Einhorn, Barbara. 1993. Cinderella Goes to Market. Citizenship, Gender and Women's Movements in East Central Europe. London, New York: Verso.

Frank, Mary Fox, Deborah G. Johnson and Sue V. Rosser, eds. 2006. Women, Gender, and Technology. Urbana, Chicago: University of Illinois Press.

Gal, Susan and Gail Kligman. 2000. The Politics of Gender After Socialism. A Comparative - Historical Essay. Princeton, New Jersey: Princeton University Press.

Game, Ann and Rosemary Pringle. 1984. Gender at Work. London: Pluto Press.

Geertz, Clifford. 1975. "Comon Sense as a Cultural System”. Antioch Review 33/1: 5-26.

Ghodsee, Kristen. 2005. The Red Riviera. Gender, Tourism and Postsocialism on the Black Sea. Durham, London: Duke University Press.

Gille, Zsuzsa. 2007. From the Cult of Waste to the Trash Heap of History. The Politics of Waste in Socialist and Postsocialist Hungary. Bloomington, Indianapolis: Indiana University Press.

Haraway, Donna J. 1991. Simians, Cyborgs and Women. The Reinvention of Nature. London, New York: Routledge.

Haraway, Donna J. 2004. The Haraway Reader. London, New York: Routledge.

Hrženjak, Majda. 2007. Nevidno delo. Ljubljana: Mirovni inštitut.

Ilić, Stanko. 1984. Put u humano društvo. Od socijalizma ka komunizmu. Beograd: Ekonomika.

Jambrešić-Kirin, Renata. 2013. "Žene u formativnom socijalizmu”. In Refleksije vremena 1945.1955. (exhibition catalog of the Klovićevi Dvori Gallery). Zagreb: Galerija Klovićevi dvori, 182-201.

Jeraj, Mateja. 2005. Slovenske na prehodu v socializem. Vloga in položaj ženske v Sloveniji 19451953. Ljubljana: Arhiv Republike Slovenije.

Jogan, Maca. 1986. "Emancipacija žensk kot sestavina množične zavesti”. In Ženske in Diskriminacija. Maca Jogan, ed. Ljubljana: Delavska enotnost, 67-83.

Kohn, Melvin. 1989. Class and Conformity. A Study in Values. London, Chicago: The University of Chicago Press.

Kolešnik, Ljiljana. 2012. "Konfliktne vizije moderniteta i poslijeratna moderna umjetnost". In Socijalizam i modernost. Umjetnost, kultura, politika 1950.-1974, Ljiljana Kolešnik, ed. Zagreb: Institut za povijest umjetnosti, 127-207.

Kollontaj, Aleksandra Mihajlovna. 1982. Ženska v socializmu. Ljubljana: Krt.

Kregar, Rado. 1937. Naš dom. Kako ga zgradimo, 2-3. Ljubljana: Žena in dom.

Krpić, Marta C. 1989. "Kuhinja prihodnosti na Domotechnici 89". Naša žena 4: 47.

Kršić, Dejan. 2012. "Grafički dizajn i vizualne komunikacije, 1950.-1975". In Socijalizam i modernost. Umjetnost, kultura, politika 1950.-1974. Ljiljana Kolešnik, ed. Zagreb: Institut za povijest umjetnosti, 209-58. 
Lipovšek, Marjan. 1991. "Tihi, nepogrešljivi član gospodinjstva”. Naša žena 6: 52-3.

Lupton, Ellen. 1993. Mechanical Brides. Women and Machines from Home to Office. New York: Princeton Architectural Press.

Lury, Celia. 1996. Consumer Culture. Cambridge, Oxford: Polity Press.

Luthar, Breda. 2006. "Remembering Socialism. On Desire, Consumption and Surveillance". Journal of Consumer Culture 6/2: 229-259.

Luthar, Breda and Maruša Pušnik. 2010. "Introduction. The Lure of Utopia: Socialist Everyday Spaces". In Remembering Utopia. The Culture of Everyday Life in Socialist Yugoslavia, Breda Luthar and Maruša Pušnik, eds. Washington: New Academia, 1-33.

Mead, Margaret. 1962. Sex and Temperament in Three Primitive Societies. New York: New American Library.

Nanda, Serena. 1999. Neither Man nor Woman. The Hijras of India. Belmont, Boston, Tokyo: Wadsworth Publishing Company.

Oakley, Ann. 2003. "Interviewing Women. A Contradiction in Terms". In Turning Points in Qualitative Research. Tying Knots in a Handkerchief. Yvonna S. Lincoln and Norman K. Denzin, eds. Oxford: AltaMira Press, 243-264.

Orehovec, Martina. 1997. “Delo Istrank v Trstu”. Etnolog 7/58: 115-129.

Patico, Jennifer and Melissa L. Caldwell. 2002. "Consumers Exiting Socialism. Ethnographic Perspectives on Daily Life in Post-Communist Europe". Ethnos 67/3: 285-94.

Patterson, Patric Hyder. 2011. Bought and Sold. Living and Losing the Good Life in Socialist Yugoslavia. Ithaca: Cornell University Press.

Pence, Katherine. 2008. "Women on the Verge. Consumers between Private Desires and Public Crisis". In Socialist Modern. East German Everyday Culture and Politics. Katherine Pence and Paul Betts, eds. Ann Arbor: The University of Michigan Press, 287-322.

Pence, Katherine and Paul Betts. 2008. "Introduction". In Socialist Modern. East German Culture and Politics. Katherine Pence and Paul Betts, eds. Ann Arbor: The University of Michigan Press, 1-34.

Povoden, V. 1955. "Razbremenimo gospodinje z mehanizacijo pranja”. Sodobno gospodinjstvo 15: 58-62.

Pušnik, Maruša. 2010. "Flirting with Television in Socialism. Proletarian Morality and the Lust for Abundance". In Remembering Utopia. The Culture of Everyday Life in Socialist Yugoslavia. Breda Luthar and Maruša Pušnik, eds. Washington: New Academia, 227-58.

Ramšak, Mojca. 2002. "Znanost med objektivnostjo in grožnjo subjektivnosti. Vloga terenskih dnevnikov in empatije pri zapisovanju življenjskih zgodb". Traditiones 31/2: 93-114.

Redfern, Paul A. 2003 "A New Look at Gentrification. Gentrification and Domestic Technologies". In The Consumption Reader. David B. Clarke, Marcus A. Doel and Kate M. L. Housiaux, eds. London, New York: Routledge, 122-6.

de Regt, Marina. 2009. "About Cleanliness, Closeness and Reability. Somali and Ethiopian Domestic Workers in Yemen". In Gender, Migration and the Public Sphere, 1850-2005. Marlou Schrover and Eileen Janes Yeo, eds. London, New York: Routledge, 140-159.

Reid, Susan E. 2007. "Gender and the Destalinization of Consumer Taste in the Soviet Union Under Khrushchev". In Gender and Consumption. Domestic Cultures and the Commercialisation of Everyday Life. Lydia Martens and Emma Casey, eds. Hampshire, Burlington: Ashgate, 49-69.

Rendla, Marta. 2015. “Življenjska raven Slovencev v drugi Jugoslaviji”. In Slovenija v Jugoslaviji. Zdenko Čepič, ed. Ljubljana: Inštitut za novejšo zgodovino, 172-99. 
Repe, Božo. 1998. “'Tihotapijo vse, razen ptičjega mleka'. Vpliv nakupovalnega turizma na kulturne spremembe in način življenja v Sloveniji po drugi svetovni vojni". Zgodovina za vse: vse za zgodovino 2: 90-6.

Riessman, Catherine Kohler. 1987. "When Gender is not Enough. Women Interviewing Women". Gender and Society 2/1: 172-207.

Ritchie, Donald A. 1995. Doing Oral History. New York: Twayne Publishers.

Rž. 1960. "Nekaterim celjskim gospodinjam ni treba več prati doma”. Sodobno gospodinjstvo 3-4: 7.

Schor, Juliet B. 1992. The Overworked American. The Unexpected Decline of Leisure. New York: BasicBooks.

Senjković, Reana. 2008. Izgubljeno u prijenosu. Pop iskustvo soc kulture. Zagreb: Institut za etnologiju i folkloristiku.

Spiler, Franc. 1956. "Slovenska imena novih gospodinjskih aparatov". Sodobno gospodinjstvo 28: $50-51$.

Squires, Judith. 2009. Spol v politični teoriji. Ljubljana: Krtina.

Stanley, Liz. 1992. The Auto/biographical, 1. Oxford, New York: Manchester University Press.

Stokes, Raymond G. 2000. Constructing Socialism. Technology and Change in East Germany, 1945-1990. Baltimore, London: The Johns Hopkins University Press.

Swafford, Kevin. 2007. Class in Late-Victorian Britain. The Narrative Concern with Social Hierarchy and its Representation. New York: Cambria Press.

Šadl, Zdenka. 2002. "Emocionalno delo in intimni odnosi v pozni moderni". Družboslovne razprave 39: 59-71.

Thompson, Paul. 2000. The Voice of the Past. Oral History. Oxford, New York: Oxford University Press.

Tomšič, Vida. 1954. “Iz zveznega posvetovanja o gospodinjskem šolstvu v Ljubljani”. Sodobno gospodinjstvo 7: 98-101.

Tomšič, Vida. 1955. "Kako gledamo socialisti na gospodinjstvo in njegov razvoj”. Sodobno gospodinjstvo 2/13-14: 2-8.

Tomšič, Vida. 1958. "Stanovanjska skupnost - oblika lastne skrbi za sebe". Sodobno gospodinjstvo 51/3: 66-67.

Anonymus. 1959. "Ali more moderna tehnika olajšati gospodinjska dela?" Sodobno gospodinjstvo 69/9: 243-5.

Anonymus. 1984. "Bela tehnika samo na ogled". Naša žena 7/8: 5.

Verdery, Katherine. 1994. "From Parent-State to Family Patriarch. Gender and Nation in Contemporary Eastern Europe”. East European Politics and Societies 8/2: 225-55.

Vodopivec, Nina. 2007. Labirint postsocializma. Socialni spomin tekstilnih delavk in delavcev. Ljubljana: ISH publikacije.

Wolcott, Wictoria W. 2001. Remaking Respectability. African American Women in Interwar Detroit. North Carolina: The University of North Carolina Press. 


\section{"PRAVI KORAK PREMA ZADOVOLJSTVU ŽENE": PERILICA RUBLJA KAO NOVA TEHNOLOGIJA I KONSTRUKCIJA ULOGE ŽENE KAO DOMAĆICE U SOCIJALISTIČKOJ SLOVENIJI}

Ovaj se rad bavi shvaćanjem načina na koji je perilica rublja kao nova tehnologija promijenila živote ljudi u Sloveniji i Jugoslaviji u razdoblju socijalizma. Autorica opisuje tri skupine problema. Prva se skupina odnosi na istraživanje tehnološkog razvoja u socijalizmu, odnosno propitivanje perspektive potrošnje kao neuspjelog projekta socijalističke produkcije. Druga se bavi promjenama koje je uvođenje perilice rublja kao nove tehnologije donijelo u shvaćanje podjele rada između muškaraca i žena u domaćinstvu. S uvođenjem perilice rublja u domaćinstvo uočavamo da muškarci po prvi puta sudjeluju u pranju rublja zbog stereotipnog odnosa između muškaraca i tehnologije. Treća se skupina pitanja bavi uštedom vremena zbog korištenja perilice rublja te prenamjenom tog vremena u druge svrhe, budući da je perilica rublja mogla potencijalno smanjiti količinu vremena koje žene provode obavljajući kućanske poslove. Kako su žene provodile ušteđeno vrijeme, kako su ga raspoređivale i kako su ih pri tome vodili javni diskursi?

Ključne riječi: perilica rublja, kućanski poslovi, rod, tehnološki razvoj, socijalizam 